\title{
Evaluation of the responses of a wetland, tropical earthworm to heavy metal contaminated soil
}

\section{Ebenezer Olasunkanmi Dada ${ }^{1, *}$, Kelechi Longinus Njoku ${ }^{1}$, Akinniyi Adediran Osuntoki ${ }^{2}$, Modupe Olatunde Akinola ${ }^{1}$}

${ }^{1}$ Department of Cell Biology and Genetics, University of Lagos, Akoka, Yaba, Lagos

${ }^{2}$ Department of Biochemistry, University of Lagos, Akoka, Yaba, Lagos

\section{Email address:}

eodada1@yahoo.com (E. Olasunkanmi Dada)

\section{To cite this article}

Ebenezer Olasunkanmi Dada, Kelechi Longinus Njoku, Akinniyi Adediran Osuntoki, Modupe Olatunde Akinola. Evaluation of the Responses of a Wetland, Tropical Earthworm to Heavy Metal Contaminated Soil. International Journal of Environmental Monitoring and Analysis. Vol. 1, No. 2, 2013, pp. 47-52. doi: 10.11648/j.ijema.20130102.12

\begin{abstract}
In view of the global importance of wetlands in providing food and income for millions of people through agricultural activities, efforts should be geared toward identifying appropriate biomonitoring organisms for them. This study investigated the mortality and burrowing responses of Libyodrilus violaceus earthworm to heavy metals in the laboratory. The worms were subjected to heavy metal spiked soil in graded concentrations following the procedure recommended by the Organization for Economic Cooperation and Development for a period of 14 days. Zn had the highest significant mean lethal effect (6.35 \pm 4.04$)$ on this species, followed by the mixtures of $\mathrm{Zn}, \mathrm{Cd}$ (5.90 \pm 5.05$)$; $\mathrm{Zn}, \mathrm{Pb}, \mathrm{Cd}(5.40 \pm 4.5)$; $\mathrm{Zn}, \mathrm{Pb}(5.05 \pm 4.37)$, in that order. The median lethal concentration (LC 50) values for zinc $(\mathrm{Zn})$, lead $(\mathrm{Pb})$, and cadmium (Cd) obtained from the study stood at $520.06,1551.55$, and $706.66 \mathrm{mg} / \mathrm{kg}$ soil respectively. The species also showed inhibited burrowing responses to these metals in individual and combined concentrations. It is concluded that $L$. violaceus should be a candidate for consideration in assessing the health of wetland soils.
\end{abstract}

Keywords: Biomonitoring, Burrowing, Libyodrilus Violaceus, Mortality, Pollution

\section{Introduction}

The problem of environmental pollution in this age of industrial and technological explosion calls for proper monitoring and actions. The soil, which plays an outstanding role in man's existence, has become a major victim of pollution. Soil contamination and pollution is a global occurrence and concern. Reference [1] reported that there are over 80,000 contaminated sites in Australia, 40,000 in United States of America (USA), 55,000 in six European countries, 7,800 in New Zealand, and about 3 million in Asia-Pacific. These polluted sites mostly contain heavy metals and organic contaminants.

Heavy metal pollution of soil is of particular concern because of its persistence and health consequences to man, his crops, and animals [2,3,4]. Metals from anthropogenic sources form a major group of compounds involved in soil contamination $[5,6]$. These metals may eventually find their ways into man's dining table en route the food chains if such polluted soils are used for farming. Reference [4] carried out an assessment of metals present in the soil and a vegetable
(Talinum trianugulare) grown in an industrial area in Lagos, Nigeria. They found higher levels of lead $(\mathrm{Pb})$ and cadmium (Cd) in the vegetable and soil compared to those of non-industrial area. It is therefore important to deploy appropriate strategy in monitoring and evaluating soil pollutants, especially metals, and consequently take remediative interventions.

The earthworm has been widely used as a test organism for soil contamination, pollution monitoring and evaluation $[7,8,9,10,11,12]$. Some species of earthworms have been reported to be tolerant to a wide range of contaminants including heavy metals and can bioaccumulate them in large quantities in their tissues $[1,13]$. They are easy to capture and handle, have a short life-cycle, and globally distributed in many types of soil $[14,15]$. An indirect evidence of earthworms' metal tolerance is the fact that some species thrive in and can be collected from heavy metal contaminated soils [8].

There is a considerable volume of work and research on earthworms' positive roles in agroecosystems, environmental monitoring and sustainability $[11,12,16,17,18]$. 
However, the majority of the species worked upon are native to temperate region. In addition, published earthworm research in Nigeria and West Africa region have been mainly on friable soil species [19].

Wetlands are important for the livelihoods of many millions of people globally by providing food and income [20]. In Nigeria, wetland environments are so important that both the Federal and State Governments have created River Basin Authorities to provide irrigation during the dry season to ensure all-year-round cropping [21]. Earthworms enhance soil fertility, total plant growth, and crop productivity by continuously burrowing, ingesting, mixing, aerating and improving the drainage of soil $[13,19]$. L. violaceous, together with other limicolus earthworms, makes a major contribution to the productivity of many river basin agricultural projects in Nigeria [19, 21]. Limicolus earthworms should therefore be appropriate biomonitoring organisms for wetlands. The aim of this study was to evaluate the behavioural and survival responses of $L$. violaceus to varying soil heavy metal levels and consequently determine its suitability in monitoring the health of wetlands. The worms were sub- jected to graduated soil concentrations of zinc ( $\mathrm{Zn})$, lead $(\mathrm{Pb})$, and cadmium $(\mathrm{Cd})$ individually, in combinations, and their responses evaluated.

\section{Materials and Methods}

\subsection{Sample Collection Site}

Soil and earthworm samples were collected from the main campus of the University of Lagos, Akoka, Lagos, Nigeria. The university is located on longitude $3^{0} 24^{\prime} \mathrm{E}$ and latitude $6^{0}$ $27^{\prime} \mathrm{N}$ within the Mainland of Lagos.

\section{2 . Soil Collection}

Sandy loamy soil [22] was used for this study. The soil was collected from the back the University of Lagos Medical Centre (the same place earthworms were collected from) at $0-2.0 \mathrm{~cm}$ depth, bulked together, air dried and passed through a $2 \mathrm{~mm}$ sieve. A portion $(10 \mathrm{~kg})$ of the bulked soil was taken to the laboratory for baseline physico-chemical analysis (Table 1).

Table 1. Physico-chemical properties of test soil

\begin{tabular}{|c|c|c|c|c|c|c|c|c|c|c|c|c|}
\hline \multirow{2}{*}{$\begin{array}{c}\% \\
\text { Sand } \\
\end{array}$} & \multirow{2}{*}{$\begin{array}{r}\% \\
\text { silt } \\
\end{array}$} & \multirow{2}{*}{$\begin{array}{c}\% \\
\text { clay }\end{array}$} & \multirow{2}{*}{$\begin{array}{c}\% \\
\text { ToC* } \\
\end{array}$} & \multirow{2}{*}{$\begin{array}{c}\% \\
\text { moist** } \\
\end{array}$} & \multirow[b]{2}{*}{$\mathrm{pH}$} & \multicolumn{3}{|c|}{$\operatorname{Metals}(\mathrm{mg} / \mathrm{kg})$} & \multicolumn{4}{|c|}{$* * \mathrm{CEC}(\mathrm{meg} / 100 \mathrm{~g})$} \\
\hline & & & & & & $\mathrm{Zn}$ & $\mathrm{Pb}$ & $\mathrm{Cd}$ & $\mathrm{Na}^{+}$ & $\mathrm{K}^{+}$ & $\mathrm{Mg}^{+}$ & $\mathrm{Ca}^{+}$ \\
\hline 69 & 14 & 14 & 2.78 & 7.59 & 6.90 & 2.94 & 0.24 & $* N D$ & 5.87 & 4.07 & 8.17 & 14.71 \\
\hline
\end{tabular}

\subsection{Earthworm Collection}

L. violaceus earthworms were collected by digging with a shovel to an average depth of $22 \mathrm{~cm}$ and hand sorting. The collection was limited to a particular area to reduce variability [23]. The worms were adults with clitella with average life weight of $0.8 \mathrm{~g}$. Worms were stabilized in soil collected from the same site $(0-2.0 \mathrm{~cm}$ deep) for at least 24 hours before use. The choice of $L$. violaceus for this study stems from its all-year-round availability, outstanding abundance in the marsh, it is a true soil dwelling species, and the fact that it makes a major contribution to the productivity wetland soils.

\subsection{Earthworm Identification}

L. violaceus is a West Africa earthworm species belonging to the family Eudrilidae. It is described to varying extent by $[24,25,26]$. It is an endogeic (soil dwelling), limicolous species, that is, unlike most friable soil earthworms, available all year round in the wild. The species is widely distributed in the middle belt down south of Nigeria and in Cameroon. It makes a major contribution to the productivity of wetland soils in Nigeria [21]. It is unpigmented with round segmentation. It has an annular (ring form) and pinkish clitellum between segments 13 and 18. The female pore appears as a pair of humid clear zones between segments 13 and 14, while the male pore is unpaired and pinkish between segments 17 and 18. It has no dorsal pore. The species was authenticated by Professor S. O. Owa of Landmark University, Omu-Aran, Kwara State, Nigeria.

\subsection{Test Reagents}

Nitrate salts of heavy metals were used namely: zinc nitrate hexahydrate $\left[\mathrm{Zn}\left(\mathrm{NO}_{3}\right)_{2} \cdot 6 \mathrm{H}_{2} 0\right]$, lead nitrate $\left[\mathrm{Pb}\left(\mathrm{NO}_{3}\right)_{2}\right]$, and cadmium nitrate tetrahydrate $\left[\mathrm{Cd}\left(\mathrm{NO}_{3}\right)_{4} \cdot 4 \mathrm{H}_{2} \mathrm{O}\right]$. Deionized water was obtained from the Chemistry Department of the University of Lagos. All test reagents used were analytical grade from Kem Light Laboratories PVT Limited, India

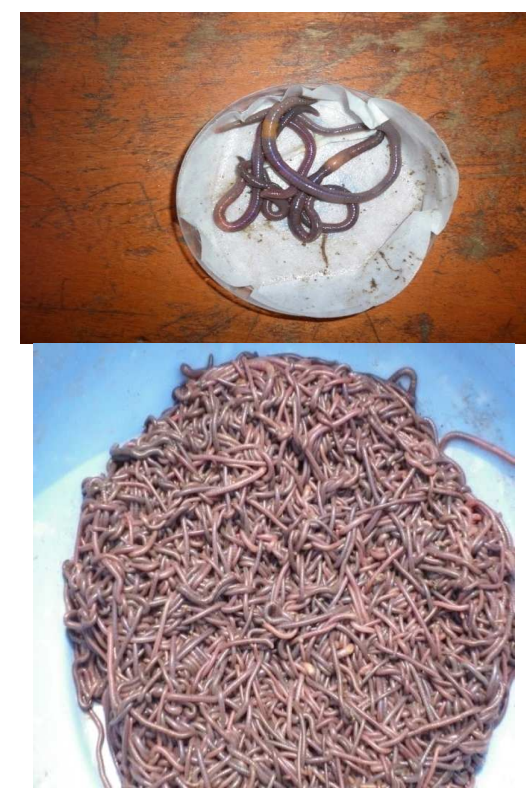

Figures 1(a) and (b). Libyodrilus violaceus 


\subsection{Tolerance Test Procedure}

The tolerance test was carried out according to the procedure of [7]. Field soil was used instead of artificial soil [22], and transparent plastic containers instead of glass [27]. Each test container measured $14 \mathrm{~cm}$ in length, $9 \mathrm{~cm}$ in breadth, and $7 \mathrm{~cm}$ in height.

Worms were subjected to five joint and individual graded concentrations of the heavy metals $(\mathrm{Zn}, \mathrm{Pb}, \mathrm{Cd})$. The appropriate quantities of nitrate salts of the metals were dissolved in $250 \mathrm{ml}$ deionized water and used to spike the sieved soil to simulate natural contamination with $\mathrm{Zn}, \mathrm{Pb}$, and $\mathrm{Cd}$ metals. The spiking of the soil with metals was in 7 groups as follows: Group A -Mixture of $\mathrm{Zn}, \mathrm{Pb}, \mathrm{Cd}$; Group B -Mixture of Zn, Pb; Group C - Mixture of Zn, Cd; Group D - Mixture of Pb, Cd; Group E - Zn; Group F - Pb; Group G - Cd. Each group was spiked with five different concentrations (Table 2) in a geometric series in four replicates each. Hence, there were 144 test containers including the control. To each test container was put $750 \mathrm{mg}$ soil. The soil in each container was thoroughly mixed for at least 5 minutes to achieve an even distribution of the metals. The set-ups were allowed to stabilize for 24 hours after mixing.

Table 2. Spiking and *final concentrations of test soil heavy metals (mg/kg)

\begin{tabular}{lllll}
\hline Concentration Level & & Zn & Pb & Cd \\
\hline 1 & Spiking & 200.00 & 150.00 & 5.00 \\
& Final & 202.94 & 150.24 & 5.00 \\
2 & Spiking & 400.00 & 300.00 & 10.00 \\
& Final & 402.94 & 300.24 & 10.00 \\
3 & Spiking & 800.00 & 600.00 & 20.00 \\
& Final & 802.94 & 600.24 & 20.00 \\
4 & Spiking & 1600.00 & 1200.00 & 40.00 \\
& Final & 1602.94 & 1200.24 & 40.00 \\
5 & Spiking & 3200.00 & 2400.00 & 80.00 \\
& Final & 3202.94 & 2400.24 & 80.00 \\
\hline
\end{tabular}

*Final concentrations arrived at after factoring in the soil metal background levels as indicated in Table 1

Ten earthworms were placed on the surface of the soil in each container. The containers were covered with perforated lids to prevent worms from escaping, allow sufficient air, and prevent excessive water loss. To ensure that worms remain in the test medium throughout the duration of the test, testing was done under continuous light at the prevailing room temperature $\left(22-31{ }^{\circ} \mathrm{C}\right)$. The time taken for all worms to burrow in each metal concentration level was recorded. Readings were taken only where all worms burrowed. Inability of one or more worms to burrow was taken an evidence of avoidance [28]. Mortality was assessed at 7 and 14 days. Worms were regarded dead if they did not respond to a mechanical stimulus at the front end. After the 7-day assessment, worms and media were put back into the test containers. The $\mathrm{pH}$ of the soil medium used was 6.9 and moisture content was made up to $35 \%$ (Table 1 )

\subsection{Analysis of Data}

The 7 and 14-day mortality data were subjected to one-way analysis of variance (ANOVA). Least Significance Differences (LSD) was used to determine the level of significance, at $\mathrm{p}<0.05$, among the results. Probit analysis for median lethal concentrations (LC50) for the metals was carried out. Two-tailed Pearson correlation co-efficient was calculated for 7 and 14-day LC50 values. All analysis were carried out with the SPSS software, 17.0 version.

\section{Results}

The descriptive statistics for the mortality of $L$. violaceus is presented in table 3, the LC 50 values for 7 and 14 - day of individual and joint metals mixtures investigated are presented in Figure 2, while the time taken for all worms to burrow in each concentration level is presented in table 5 .

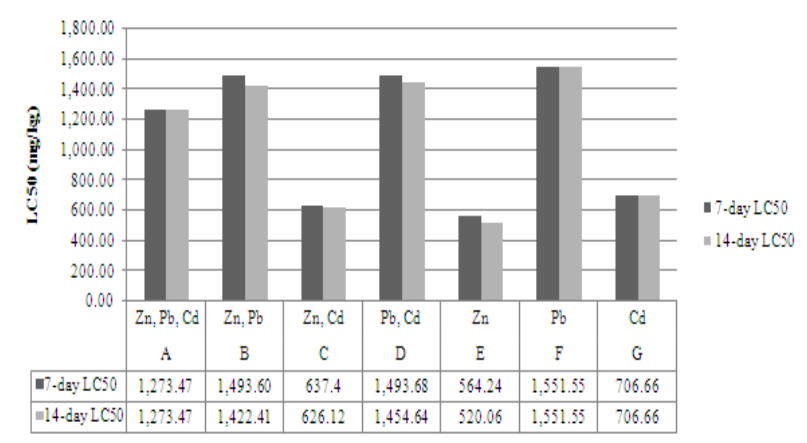

Figure 2. LC 50 values for 7 and 14 -day mortality assessment.

When compared with the control, L. violaceus showed significantly higher mortality (Table 3 ) to all metal mixtures where $\mathrm{Zn}$ was present. $\mathrm{Zn}$ had the highest significant mean mortality (6.35 \pm 4.04$)$, followed by the binary mixtures of $\mathrm{Zn}$ and $\mathrm{Cd}(5.90 \pm 5.05)$, the triple mixture of $\mathrm{Zn}, \mathrm{Pb}, \mathrm{Cd}$ (5.40 \pm 4.50$)$, and the binary mixture of $\mathrm{Zn}$ and $\mathrm{Pb}(5.05 \pm 4.37)$ in that order. There was a strong, positive correlation $[\mathrm{r}(5)$ $=.99, \mathrm{P}<0.01]$ between the 7 and $14-$ day LC 50 values when a Pearson correlation coefficient was calculated for them. For the control group, all worms burrowed within 5 minutes and there was no mortality. The 14 - day LC 50 values for $\mathrm{Zn}, \mathrm{Pb}$ and $\mathrm{Cd}$ individual metals were 520.06, 1551.55 and $706.66 \mathrm{mg} / \mathrm{kg}$ soil respectively. The 7 and 14-day LC 50 values for $\mathrm{Pb}$ and $\mathrm{Cd}$ remained constant while the 14-day LC 50 value for $\mathrm{Zn}$ decreased to $520.06 \mathrm{mg} / \mathrm{kg}$ soil from the $564.24 \mathrm{mg} / \mathrm{kg}$ value for 7-day. For heavy metal binary mixture effects on L. violaceous, the pair of $\mathrm{Zn}$ and $\mathrm{Cd}$ (Group C) was the most toxic with a 14-day LC 50 value of $626.12 \mathrm{mg} / \mathrm{kg}$ soil. The corresponding LC 50 values for the pairs of $\mathrm{Zn}$ and $\mathrm{Pb}$ (Group B), $\mathrm{Pb}$ and $\mathrm{Cd}$ (Group D) were 1422.41 and $1454.64 \mathrm{mg} / \mathrm{kg}$ soil respectively. The combined action of the three metals $(\mathrm{Zn}, \mathrm{Pb}, \mathrm{Cd})$ as represented by group A gives a 14-day LC 50 value of $1,273.47 \mathrm{mg} / \mathrm{kg}$ soil.

The burrowing responses as presented in Table 4 indicate that in groups A, B, C and E, where $\mathrm{Zn}$ was present, $L$. violaceus showed avoidance behaviour because total burrowing was not achieved in all the concentration levels. In group $\mathrm{A}(\mathrm{Zn}, \mathrm{Pb}, \mathrm{Cd})$ and $\mathrm{C}(\mathrm{Zn}, \mathrm{Cd})$, total worm burrowing occurred only in concentration levels 1-3. In groups B (Zn, 
$\mathrm{Pb})$, and $\mathrm{E}(\mathrm{Zn})$, total burrowing occurred in concentrations 1-4 howbeit at varying time intervals. In groups D, F, and G, all the worms in each concentration level burrowed within a relatively shorter time (5-20 minutes). The worms in concentration levels 1-3 of Cd - spiked soil (Group G) burrowed within 5 minutes. The corresponding burrowing time for $\mathrm{Pb}$ - spiked soil (group F) was 5-7 minutes, and Zn - spiked soil (group E) was 10-40 minutes.

Table 3. The descriptive statistics and level of significance on the mortality of $L$. violaceus for different metal mixture groups when compared with the control.

\begin{tabular}{llc}
\hline Group & Metal combination & Mean mortality \\
\hline A & $\mathrm{Zn}, \mathrm{Pb}, \mathrm{Cd}$ & $5.40 \pm 4.51^{*}$ \\
$\mathrm{~B}$ & $\mathrm{Zn}, \mathrm{Pb}$ & $5.05 \pm 4.37^{*}$ \\
$\mathrm{C}$ & $\mathrm{Zn}, \mathrm{Cd}$ & $5.90 \pm 5.00^{*}$ \\
$\mathrm{D}$ & $\mathrm{Pb}, \mathrm{Cd}$ & $2.45 \pm 4.01$ \\
$\mathrm{E}$ & $\mathrm{Zn}$ & $6.35 \pm 4.04^{*}$ \\
F & $\mathrm{Pb}$ & $2.15 \pm 4.04$ \\
G & $\mathrm{Cd}$ & $0.05 \pm 0.22$ \\
Control & $\mathrm{No}$ metal & 0.00 \\
\hline
\end{tabular}

*The mean difference is significant at $p<0.05$ (LSD)

Table 4. ANOVA table of the mean mortality of L. violaceus for different metal group

\begin{tabular}{lrrrrr}
\hline Sum of squares & Df & Mean square & \multicolumn{2}{l}{ F } & \multicolumn{2}{l}{ Significance } & \\
\hline Between groups & 730.61 & 7 & 104.37 & 6.63 & 0.00 \\
Within groups & 2142.55 & 136 & 15.75 & & \\
Total & 2873.16 & 143 & & & \\
\hline
\end{tabular}

Table 5. Time taken for all worms to burrow in each group concentration level [minutes]

\begin{tabular}{lcccccccc}
\hline $\begin{array}{l}\text { Group } \\
\text { ( A }\end{array}$ & B $, \mathrm{Pb}, \mathrm{Cd})$ & $(\mathrm{Zn}, \mathrm{Pb})$ & $(\mathrm{Zn}, \mathrm{Cd})$ & $(\mathrm{Pb}, \mathrm{Cd})$ & $(\mathrm{Zn})$ & $(\mathrm{Pb})$ & $(\mathrm{Cd})$ \\
\hline *Conc & & & & & & & $\mathrm{F}$ & \\
1 & 8 & 8 & 10 & 5 & 10 & 5 & 5 \\
2 & 8 & 9 & 14 & 5 & 14 & 5 & 5 \\
3 & 12 & 9 & 35 & 7 & 40 & 7 & 5 \\
4 & $* \mathrm{NB}$ & 25 & $* \mathrm{NB}$ & 12 & 40 & 10 & 7 \\
5 & $* \mathrm{NB}$ & $* \mathrm{NB}$ & $* \mathrm{NB}$ & 20 & $* \mathrm{NB}$ & 16 & 7 \\
\hline
\end{tabular}

*Conc-Concentration level *NB-No total burrowing

\section{Discussion}

In this study, $\mathrm{Zn}$ had the highest significant mean lethal effect on L. violaceus $(6.35 \pm 4.04)$ when compared with the control that recorded no mortality. The LC 50 value for $\mathrm{Zn}$ was also the lowest $(520.06 \mathrm{mg} / \mathrm{kg}$ soil) compared to those of $\mathrm{Pb}$ and $\mathrm{Cd}$ which stood at $1,551.55$ and $706.66 \mathrm{mg} / \mathrm{kg}$ soil respectively. This indicates that $\mathrm{Zn}$ is the least tolerated and therefore the most toxic, and $\mathrm{Cd}$, the most tolerated, and therefore, the least toxic to L. violaceus. Whereas the 7 and 14-day LC 50 values remained constant for $\mathrm{Pb}$ and $\mathrm{Cd}$, implying no further lethal effect beyond 7 days, the lethality of $\mathrm{Zn}$ continued beyond 7 days. These results agree with the findings of [8,29]. Reference [29] concluded that reductions in earthworm populations around polluted sites are probably due to the effects of $\mathrm{Zn}$ and not other metals like $\mathrm{Cd}, \mathrm{Cu}$, and $\mathrm{Pb}$. Reference [8] investigated the evolution of $\mathrm{Zn}$ resistance in Eisenia fetida and concluded that there is a low resistance to $\mathrm{Zn}$ when compared with $\mathrm{Cd}$.

It was observed from the results presented in this study that $L$. violaceus manifested signs of burrowing difficulty in all cases where $\mathrm{Zn}$ was present. Since lack of burrowing response is an indicator of soil toxicity [28], the relative delayed or non-burrowing responses shown by the species when $\mathrm{Zn}$ was present is a further confirmation of $\mathrm{Zn}$ toxicity. The extra toxicity associated with $\mathrm{Zn}$ has been attributed to the fact that, being an essential element, it is difficult to eliminate $[8,22]$. The toxic responses shown to $\mathrm{Zn}$ contaminated soil in this study suggests that $L$. violaceus is a good biomonitoring candidate for $\mathrm{Zn}$ pollution in wetland soils. The relatively higher LC 50 value $(1551.55 \mathrm{mg} / \mathrm{kg}$ soil) for $\mathrm{Pb}$ indicates better tolerance by this species. Reference [11] compiled a list of LC 50 values derived from other published data for $\mathrm{As}, \mathrm{Cu}, \mathrm{Pb}, \mathrm{Zn}$ on some worms and observed a generally low toxicity associated with $\mathrm{Pb}$. Therefore $L$. violaceus must be behaving true to type by showing more relative tolerance to $\mathrm{Pb}$. However, when the LC 50 value for $\mathrm{Pb}(1551.55 \mathrm{mg} / \mathrm{kg}$ soil $)$ derived from this study is compared with those of other species compiled by [11], L. violaceus is only moderately tolerant to $\mathrm{Pb}$. For instance, while the $\mathrm{Pb}$ LC 50 value in this study stood at $1551.55 \mathrm{mg} / \mathrm{kg}$ soil, other species' such as Pheretima spp., Pheretima guellelmi, and Eisenia fetida ranged between 1,382 and 5,941 mg/kg soil. Since these other species are used for toxicity monitoring in friable soils [11, 12, 22], L. violaceus should be an ideal biomonitoring candidate for heavy metals in wetland soils. The relatively higher LC 50 value $(1422.41 \mathrm{mg} / \mathrm{kg})$ of the binary mixture of $\mathrm{Zn}$ and $\mathrm{Pb}$ compared to other metal mixtures where $\mathrm{Zn}$ was present in this study, suggests a degree of antagonistic relationship. $\mathrm{Pb}$ must have inhibited the adverse effects of $\mathrm{Zn}$ on the L. violaceus. The species showed no obvious negative response to $\mathrm{Cd}$ except when present in combination with other metals. This is probably due to the low concentration of the metal used in this study. As a result, higher concentrations will have to be used in future studies to establish the suitability of this species for Cd monitoring in wetland soils.

\section{Conclusions}

In view of the global importance of wetlands in proving food and income for millions of people through agricultural activities, there is the need to identify appropriate biomonitoring organisms for these soils. This study has shown that 
L. violaceus is a candidate of choice to monitor the health of wetlands especially zinc and lead pollution. Unlike the epigeic (soil surface dwelling) and anecic (deep soil dwelling) earthworms which may be less exposed to pollutants including heavy metals due to their behavioural, life cycle, and feeding characteristics, L. violaceus is an endogeic species which lives in and feeds on mid-layer soils where metals and other pollutants might have accumulated over a long period of time. Although this earthworm is native to West Africa, it may be transplanted to wetlands of other regions just like the popular Eudrilus euginiae, which though native to West Africa, is now globally distributed. Such transplantations will not only help monitor the health, but also increase the productivity of those wetlands. However, the issues of environmental compatibility and invasiness must be put into consideration.

\section{Acknowledgements}

The authors are grateful to Prof. S. O. Owa of Landmark University, Omu-Aran, Kwara State, Nigeria, for identifying the earthworms used for this study and for the release of texts and journal materials which facilitated the smooth conduct of the research.

\section{References}

[1] Sinha R. K., Bharambe G Ryan, D. 2008. Converting wasteland into wonderland by earthworms - a low-cost nature's technology for soil remediation: A case study of vermiremediation of PAH contaminated soil. The Environmentalist, 28 (4), 466-475.

[2] Clark RB. Marine Pollution. 1992. Clarendon Press, Oxford, UK, 61-79.

[3] Akinola M.O., Njoku K. L., Ifitezue N. V. 2011 Assessment of heavy metals (lead and cadmium) concentration in Paspalum orbiculare near municipal refuse dumpsites in Lagos State, Nigeria. Journal of Ecology and Natural Environment, 3 (16), 509-514.

[4] Akinola M.O., Njoku K. L., Ekeifo, B. E. 2008. Determination of lead, cadmium and chromium in the tissue of an economically important plant grown around a textile industry at Ibeshe, Ikorodu Area of Lagos State, Nigeria. Advances in Environmental Biology, 2 (1), 25-30.

[5] Lobersli E. M., Steines E.1988. Metal uptake in plants from a birch forest area near a copper smelter in Norway. Water, Air, Soil Pollution, 37, 25-39.

[6] Yaron B., Calvet, R. Prost, R. 1996. Soil Pollution. Springer-Verlag, Berlin.

[7] Organization for Economic Co-operation and Development (OECD). 1984. Earthworm acute toxicity tests. OECD Guidelines for Testing of Chemicals, 207.

[8] Spurgeon D. J., Hopkin S. P. 2000. The development of genetically inherited resistance to zinc in laboratory - selected generations of the earthworm, Eisenia fetida. Environmental Pollution, 109, 193-201.
[9] Reinecke S. A., Reinecke A. J. 2004. The comet assay as biomarker of heavy metal genotoxicity in earthworms. Archives of Environmental Contamination and Toxicology, 46, 208-215.

[10] Smith R., Pollard S. J. T., Weeks J. M., Nathanail C.P. 2005. Assessing significant harm to terrestrial ecosystems from contaminated Land. Soil Use and Management, 21, 527-540.

[11] Shin K., Kim J., Kim K. Earthworm toxicity test for the monitoring arsenic and heavy metal - containing mine tailings. Environmental Engineering Science. 2007, 24 (9), 1257-1265.

[12] Hirano T., Tamae K. Earthworms and soil pollutants. Sensors. 2011, 11, 11157-11167. (www.mdpi.com/journal/sensors).

[13] Sinha R. K., Chauhan K., Valani D., Chandran V., Soni B. K., Patel V. 2010. Earthworms: Charles Darwin's 'Unheralded Soldiers of Mankind': Protective and productive for man and environment. Journal of Environmental Protection, 1, 251-260.

[14] Fitzpatrick L. C., Muratti - Ortiz J. F., Venables B., Goven A. J. H. 1996. Comparative toxicity in earthworm Eisenia fetida and Lumbricus terrestris exposed to cadmium nitrate using artificial soil and filter paper protocols. Bulletin of Environmental Contamination and Toxicology. 57, 63-68.

[15] Ogunseitan O. A. 2002. Microbial proteins as biomarkers of ecosystem health. in Integrated Assessment of Ecosystem Health (Ed. Scow K. M., Fogg G. E., Hinton D. E., Johnson M.L.), pp. 217-232, Lewis Publishers, Florida.

[16] Maenpaa K.A., Kukkonen J. V. K., Lydy M . J. 2002. Remediation of heavy metal - contaminated soils using phosphorus: Evaluation of bioavailability using an earthworm bioassay. Archives of Environmental Contamination and Toxicology, 43, 389-398.

[17] Hickman Z. A., Reid B. J. 2008. Earthworm assisted bioremediation of organic contaminants. Environment International, 34 (7) 1072-1081.

[18] Hu C.W., Li M., Cui Y. B., Li D.S., Chen J., Yang L. Y. 2010. Toxicological effects of $\mathrm{TiO} 2$ and $\mathrm{ZnO}$ nanoparticles in soil on earthworm Eisenia fetida. Soil Biology and Biochemistry, $42,586-591$.

[19] Owa S. O., Olojo F. 2003. Limicolous earthworms of streams and river banks in Ago-Iwoye, SW Nigeria. Journal of Applied Sciences, 6(3), 3726-3737.

[20] van Dam A. A., Kaggwa R. C., Kipkemboi J. 2006. Integrated pond aquaculture in Lake Victoria Wetlands. in Integrated Irrigation and Aquaculture in West Africa: Practices and Potential (Eds Halwart M., van Dam A. A.), pp. 129-134, Rome, F.A.O.

[21] Owa S. O., Dedeke G. A., Moreyebi O. H., Morafa S.O.A., Serijobi B. A., Aladesida A. A. 2010. Partitioning of chemical effects of earthworms on growth performance of the vegetable Amaranthus. Australian Journal of Basic and Applied Sciences, 4 (8) 3755-3761.

[22] Laurenco J., Pereira R., Silva A., Carvalho F., Oliveira J., Malta M., Paiva A., Goncalves F., Mendo, S. 2012 Evaluation of the sensitivity of genotoxicity and cytotoxicity end points in earthworms exposed in situ to uranium mining wastes. Ecotoxicology and Environmental Safety, 75, 46-54. 
[23] Cholewa J., Feeney G. P., O’Reilly M., Sturzenbaum S. R., Morgan A. J., Plytycz, B. 2006. Autofluorescence in eleocytes of some earthworm species. Folia Histochemica Et Cytobiologica, 44 (1), 65-71.

[24] Beddard F. E. 1891. On the structure of an earthworm allied to Nemeortodrilus Mich., with observations on the post-embryonic development of certain organs. Quart. J. Mic. Sci. 1891, 32, 579-586.

[25] Owa S. O. 1992. Taxonomy and distribution of Nigerian earthworms of the family of Eudrilidae and their use as possible indicators of soil properties. Unpublished $\mathrm{Ph}$. D. Thesis, Obafemi Awolowo University, Ile-Ife, Nigeria, 1992.

[26] Bamgbose O., Odukoya O. O., Arowolo T.O.A. 2000.
Earthworms as bio-indicators of metal pollution in dump sites of Abeokuta city, Nigeria. Revista de Biologic Tropical, $48,1-13$.

[27] Robidoux P. Y., Hawari J., Thiboutot S., Ampleman G., Sunahara G. I. 1999. Acute toxicity of 2,4,6-trinitrotoluene in earthworm (Eisenia fetida). Ecotoxicological and Environmental Safety, 44 (3), 311-21.

[28] American Society for Testing and Materials (ASTM). 1995. Standard for conducting laboratory soil toxicity test with Lumbricid Eisenia fetida, ASTME 1676-95.

[29] Spurgeon D. J., Hopkin S. P. 1995. Extrapolation of the laboratory - based OECD earthworm toxicity test to metal contaminated field sites. Ecotoxicology,, 44 (3), 190-205. 